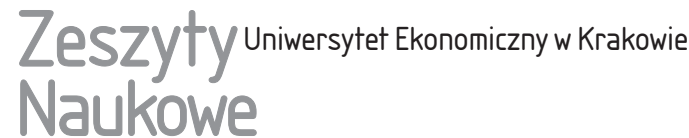

\section{Pojęcie i zakres polityki rachunkowości w polskich oraz w międzynarodowych regulacjach rachunkowości}

\section{Streszczenie}

Polityka rachunkowości jest pojęciem wieloznacznym i różnie definiowanym. Często utożsamia się ją z zasadami rachunkowości. Różnie też określany jest jej zakres.

Celem artykułu jest ukazanie istoty polityki rachunkowości w kontekście zasad rachunkowości, a w konsekwencji próba zdefiniowania tego pojęcia, przede wszystkim zaś porównanie zakresu znaczeniowego polityki rachunkowości określonego w polskich i międzynarodowych regulacjach z zakresu rachunkowości. Zastosowano takie metody badawcze, jak: analiza literatury, analiza aktów prawnych, metoda porównań oraz metoda dedukcji.

Celem opracowania było także zwrócenie uwagi na aktualny problem, jakim jest niedostosowanie polskich rozwiązań prawnych do regulacji międzynarodowych w zakresie definiowania polityki rachunkowości oraz jej zakresu przedmiotowego. Mimo że Polska sukcesywnie dostosowuje przepisy do regulacji Unii Europejskiej, kwestia zakresu polityki rachunkowości nadal nie została ujednolicona.

W wyniku przeprowadzonych analiz stwierdzono, że polityki rachunkowości nie stanowią zasady rachunkowości, lecz czynność związana z dokonywaniem wyboru tych zasad. Wybrane zasady rachunkowości są efektem zastosowanej polityki rachunkowości i świadczą o jej realizacji. Natomiast w regulacjach prawnych dotyczących rachunkowości (w polskiej ustawie o rachunkowości, MSR) utożsamia się politykę rachunkowości z zasa-

Konrad Stępień, Uniwersytet Ekonomiczny w Krakowie, Wydział Finansów i Prawa, Katedra Rachunkowości Finansowej, ul. Rakowicka 27,31-510 Kraków, e-mail: stepienk@uek.krakow.pl, ORCID: https://orcid.org/0000-0002-7920-9688. 
dami lub rozwiązaniami szczegółowymi rachunkowości, czego nie można uznać za prawidłowe. Występuje ponadto duża rozbieżność w określaniu zakresu polityki rachunkowości w polskiej ustawie o rachunkowości i MSR.

Słowa kluczowe: polityka rachunkowości, zasady rachunkowości, wielkości szacunkowe, regulacje rachunkowości.

Klasyfikacja JEL: M41.

\section{Wprowadzenie}

Sprawozdania finansowe należą do podstawowych narzędzi komunikowania się przedsiębiorstwa $\mathrm{z}$ otoczeniem gospodarczym. Będąc produktem finalnym rachunkowości, sprawozdania finansowe zawierają kompleksowe informacje o sytuacji majątkowo-kapitałowej oraz wynikach działalności podmiotów gospodarczych za dany okres sprawozdawczy, prezentowane z zastosowaniem konwencjonalnych formuł. Wielu użytkowników sprawozdań podejmuje na ich podstawie różne ważne decyzje ekonomiczne. Informacje pochodzące ze sprawozdań finansowych są także brane pod uwagę podczas oceniania, różnicowania i pozycjonowania działających na rynku przedsiębiorstw przez otoczenie.

Realizacja istotnej funkcji sprawozdań finansowych wymaga od podmiotu gospodarczego określenia, przyjęcia i stosowania odpowiedniej polityki rachunkowości, uwzględniającej specyfikę jego działalności. Obowiązek tworzenia i prowadzenia polityki rachunkowości spoczywa na kierownictwie jednostki gospodarczej, a wynika z regulacji prawnych w zakresie rachunkowości. W prawie bilansowym, jako że nie można określić wszystkich reguł rachunkowości dla każdego podmiotu gospodarczego, wyznacza się jedynie ogólne ramy systemu rachunkowości, cedując na kierownictwo jednostek określenie szczegółowych zasad i rozwiązań. Nałożenie na kierownictwo przedsiębiorstwa obowiązku dobrania szczegółowych rozwiązań w zakresie rachunkowości ma na celu zagwarantowanie odpowiedniej jakości sprawozdań finansowych, a więc tego, że rzeczywisty obraz sytuacji finansowej przedsiębiorstwa zostanie w nich rzetelnie i jasno zaprezentowany - zgodnie z zasadą true and fair view.

Polityka rachunkowości, mimo że odgrywa tak istotną rolę w kształtowaniu sprawozdań finansowych, bywa różnie rozumiana. W wielu wypadkach błędnie utożsamia się ją z zasadami rachunkowości. Różnie określany jest także zakres polityki rachunkowości, i to zarówno w teorii rachunkowości, jak i regulacjach prawnych $^{1}$.

${ }^{1}$ Pokrewne do pojęcia polityki rachunkowości jest pojęcie polityki bilansowej. Z uwagi na to, że polityka bilansowa nie jest formalnie regulowana przez przepisy prawa bilansowego w niniejszym opracowaniu ograniczono się wyłącznie do kwestii polityki rachunkowości. 
Wydawałoby się, że w dobie harmonizacji i konwergencji rozwiązań z zakresu rachunkowości, mających na celu zapewnienie porównywalności sprawozdań finansowych podmiotów działających na różnych rynkach i w różnych krajach, nie powinny występować znaczne rozbieżności dotyczące meritum polityki rachunkowości. Gdy jednak analizuje się polskie regulacje w zakresie rachunkowości w porównaniu z rozwiązaniami międzynarodowymi, akceptowanymi również w strukturach Unii Europejskiej, uwidaczniają się istotne różnice dotyczące zakresu polityki rachunkowości podmiotów gospodarczych. Warto zauważyć, że mimo iż Polska sukcesywnie dostosowuje swoje regulacje do regulacji Wspólnoty Europejskiej, kwestia przedmiotu polityki rachunkowości nadal nie została ujednolicona.

Celem artykułu jest ukazanie istoty polityki rachunkowości w kontekście zasad rachunkowości, a w konsekwencji próba zdefiniowania pojęcia polityki rachunkowości, a także porównanie zakresu znaczeniowego pojęcia polityki rachunkowości określonego w polskich i międzynarodowych regulacjach z zakresu rachunkowości, aby uwidocznić problem niedostosowania polskich rozwiązań prawnych do regulacji międzynarodowych w kwestii definiowania polityki rachunkowości oraz jej zakresu przedmiotowego, co z pewnością nie przyczynia się do zapewnienia porównywalności informacji sprawozdawczych. Zastosowano następujące metody badawcze: analizę literatury przedmiotu, analizę aktów prawnych, metodę porównań oraz metodę dedukcji.

\section{Pojęcie polityki rachunkowości w kontekście zasad rachunkowości}

Pojęcie polityki rachunkowości jest wieloznaczne i różnie definiowane w teorii rachunkowości. Zostało ono wprowadzone do polskiej nauki o rachunkowości przez W. Brzezina (2000, s. 34) w 1966 r. w znaczeniu „całej sfery normalizacji rachunkowości poprzez różnego rodzaju przepisy prawne, standardy, dyrektywy metodologiczne celem skonkretyzowania zasad rachunkowości w danym państwie (wspólnocie państw) w pewnym okresie czasu". Z czasem jednak autor ten zaczął wyróżniać dwa wymiary polityki rachunkowości: makropolitykę rachunkowości oraz mikropolitykę rachunkowości. Jego zdaniem ,makropolityka rachunkowości ustala pewien model rachunkowości w danym państwie lub tworzy wzorce do przymusowego lub dobrowolnego naśladownictwa poprzez: ustawy, standardy, dyrektywy metodologiczne”, mikropolityka rachunkowości to natomiast „kształtowanie sprawozdań finansowych zgodnie z celami ustalonymi przez właściciela podmiotu, ale w ramach obowiązujących przepisów i standardów rachunkowości" (Brzezin 2000, s. 35). Poza tym W. Brzezin wiązał ustanowienie standardów rachunkowości z ograniczeniem swobody w kształtowaniu podstawowych zasad 
rachunkowości (wymiar makro), postanowienia (ustalenia, wytyczne) ujęte w tych standardach łączył zaś z zasadami rachunkowości przyjętymi w danym przedsiębiorstwie (wymiar mikro).

A. Karmańska (2010, s. 101-102) wyróżniła aż trzy wymiary polityki rachunkowości, tj. globalny, makroekonomiczny oraz mikroekonomiczny. Stwierdziła, że: „o polityce rachunkowości w aspekcie globalnym można mówić, gdy z perspektywy pewnej grupy państw (wyróżnionej kulturowo lub w drodze porozumień międzynarodowych) zostanie określony sposób funkcjonowania systemów informacyjnych rachunkowości podmiotów prowadzących w tych państwach działalność gospodarczą. Globalna polityka rachunkowości sprowadza się do przesądzenia przez grupę państw, w jakim kształcie rachunkowość ma w tych państwach funkcjonować:

1) czy ma to być system standaryzowany (taki sam, ujednolicony w zakresie zalecanego wachlarza metod, reguł i zasad) dla wszystkich państw z tej grupy, lub

2) dopuszcza się równoległe występowanie różnych systemowych rozwiązań (w każdym państwie innego wachlarza metod, reguł i zasad), albo

3) zastosuje się wariant kompromisowy, w świetle którego zachowa się obligatoryjność przestrzegania jedynie fundamentalnych ram opisu rzeczywistości gospodarczej i pozostawi swobodę wyboru co do rozwiązań szczegółowych, oraz wokół jakiej koncepcji zachowania kapitału będą się koncentrowały zasady, metody i rozwiązania zalecane do zastosowania w ustalonej globalnej polityce rachunkowości”. Autorka pisze dalej: „wybrana na podstawie zasad i przesłanek współpracy międzynarodowej wersja globalnej polityki rachunkowości nabiera pełnego kształtu w drodze ustalenia zestawu zalecanych do stosowania - koncepcji, zasad, metod, reguł i rozwiązań szczegółowych”.

Polityka rachunkowości w ujęciu makroekonomicznym oznacza z kolei według A. Karmańskiej (2010, s. 103) „,podjęcie decyzji co do koncepcji budowy porządku prawnego obowiązującego $\mathrm{w}$ danym państwie $\mathrm{w}$ zakresie tworzenia informacji sprawozdawczej wykorzystywanej szeroko, przez różne grupy interesariuszy praktyki gospodarczej. Makroekonomiczna polityka rachunkowości określa niesprzeczny z globalną polityką rachunkowości (jeśli dane państwo obowiązuje) zestaw rozwiązań zalecanych do stosowania w ramach polityki rachunkowości w ujęciu mikroekonomicznym".

Mikropolityka rachunkowości jest natomiast zdaniem A. Karmańskiej najpierw efektem globalnej polityki rachunkowości, a następnie makroekonomicznej polityki rachunkowości. Jest to: ,wybrany do stosowania na poziomie mikroekonomicznym wachlarz koncepcji, metod, zasad, reguł, zaleceń i rozwiązań odnoszących się do rachunkowości każdego podmiotu gospodarczego zobowiązanego do jej prowadzenia. Jeżeli w tym wachlarzu istnieją pola swobodnego wyboru, to każdy podmiot gospodarczy, kierując się dążeniem do zapewnienia wiernego 
obrazu rzeczywistości gospodarczej podmiotu, wybiera rozwiązania określające jego politykę w obszarze swojej rachunkowości, tj. ustala mikroekonomiczną politykę rachunkowości. Politykę tę stanowi zestaw rozwiązań, według których przedsiębiorstwo ustala i prezentuje informację finansową o swojej działalności, respektując normy prawa bilansowego wpisanego - poprzez zastosowanie polityki rachunkowości w skali makroekonomicznej - w ład gospodarczy danego kraju" (Karmańska 2010, s. 105).

Analizując to ciekawe ujęcie przez A. Karmańską wielowymiarowości polityki rachunkowości, warto zwrócić uwagę na to, że autorka w wypadku każdego z wymienionych wymiarów raczej utożsamia pojęcie polityki rachunkowości z koncepcjami, metodami, zasadami i rozwiązaniami rachunkowości, a więc, jak się wydaje, z przedmiotem tej polityki.

Inni autorzy, definiując pojęcie polityki rachunkowości, odnoszą się zazwyczaj do jej mikrowymiaru. Według E.A. Hendriksena i M.F. van Bredy (2002, s. 250) ,polityka rachunkowości jest zbiorem standardów rachunkowości, opinii, interpretacji, reguł oraz przepisów wykorzystywanych przez przedsiębiorstwa w ich sprawozdawczości finansowej”. Warto zauważyć, że autorzy ci utożsamiają politykę rachunkowości z zasadami rachunkowości stosowanymi przez podmiot gospodarczy podczas sporządzania sprawozdania finansowego.

W podobny sposób politykę rachunkowości ujmują D.E. Kieso i J.J. Weygandt (1992, s. 1391), zdaniem których „polityka rachunkowości jednostki to ściśle określone zasady i metody rachunkowości, bieżąco stosowane i uznane za najbardziej odpowiednie, aby przedstawiać rzetelnie sprawozdanie finansowe przedsiębiorstwa". Autorzy ci także utożsamiają politykę rachunkowości z zasadami rachunkowości.

W zbliżony sposób politykę rachunkowości definiuje także E. Walińska (2010, s. 390), pisząc, że ,polityka rachunkowości obejmuje zasady, metody i procedury, przyjęte przez kierownictwo przedsiębiorstwa przy sporządzaniu i prezentacji sprawozdań finansowych, a jej wybór jest prawem podmiotu gospodarczego, zagwarantowanym przepisami prawa bilansowego i zwyczajem”.

S.M. Saudagaran (2009, s. 1-13) pojęcie polityki rachunkowości wiąże z kolei z ,dokonywaniem wyborów w odniesieniu do: ogólnych celów ustalonych dla rachunkowości, ram instytucjonalnych dla określania i realizacji przepisów o rachunkowości, szczegółowych zasad rachunkowości oraz praktyk rachunkowości przedsiębiorstw”. Traktuje zatem politykę rachunkowości raczej jako czynność polegającą na dokonywaniu wyborów dotyczących różnych obszarów systemu rachunkowości.

M.W.E. Glautier i B. Underdown (1997, s. 61) określają politykę rachunkowości jako ,przyjęty przez jednostkę sposób prowadzenia rachunkowości w ramach wyznaczonych przez prawo, polegający na konsekwentnym stosowaniu przez 
przedsiębiorstwo specyficznych zasad, reguł, metod, procedur rachunkowości, które w opinii zarządu są odpowiednie do sytuacji firmy i najlepiej przedstawiają jej obraz finansowy".

W podobny sposób, bardzo ogólnie jednak, polityka rachunkowości jest definiowana przez A. Kinserdala (1995, s. 246), jako „wybrane i konsekwentnie stosowane rozwiązania rachunkowości, zwykle prezentowane w sprawozdaniu finansowym".

M. Remlein pod pojęciem polityki rachunkowości rozumie „zręczne, konsekwentne dokonywanie pomiaru, opisu i interpretowania działalności gospodarczej, zmierzające do osiągnięcia określonego celu". Należy zauważyć, że autorka nie odnosi się w tej definicji wprost do zasad rachunkowości, opisuje raczej czynności związane ze sposobem prowadzenia rachunkowości.

W polskiej literaturze przedmiotu nowatorską definicję polityki rachunkowości sformułowała w 1997 r. A. Jarugowa, zdaniem której: ,,polityka rachunkowości to zastosowanie przez zarząd przedsiębiorstwa w sporządzaniu sprawozdań finansowych specyficznych zasad, konwencji, reguł i praktyk dobranych odpowiednio do odwzorowania jego rzeczywistej pozycji finansowej, dochodowej i dokonań (...). Selekcja i zastosowanie zasad, reguł itp. określana jest mianem polityki rachunkowości, powinna być dokonywana w świetle realizacji celu, jakiemu służą sprawozdania finansowe, przy zachowaniu jakościowych charakterystyk, a w szczególności istotności informacji i jej wiarygodności (...). Jeżeli prawo czy standardy przewidują alternatywne zasady, to ujawnia się zastosowaną politykę polegającą na wyborze między przewidzianymi przez prawo bilansowe zasadami” (Jarugowa i Walińska 1997, s. 23-24). Analizując tę definicję, można zauważyć, że A. Jarugowa akcentuje bardziej samą czynność związaną z zastosowaniem, wyborem i selekcją zasad rachunkowości niż same zasady rachunkowości.

Z zaprezentowanych definicji wynika, że w wielu wypadkach polityka rachunkowości jest utożsamiana z zasadami rachunkowości. W kontekście tych spostrzeżeń warto się zastanowić, czy polityka rachunkowości jest rzeczywiście tym samym co zasady rachunkowości. W tym celu wskazane wydaje się przeanalizowanie znaczenia terminu ,polityka”.

W ogólnym ujęciu polityka (z gr. politiké - sprawy państwowe) jest to:

- „,sztuka, nauka rządzenia państwem; sprawy państwowe; organizacja, kierowanie i administracja sprawami wewnętrznymi i zagranicznymi państwa, narodu, kraju; działalność mająca na celu zdobycie, utrzymanie i wykorzystanie władzy państwowej przez daną klasę społeczną albo jej odłam; potocznie: postępowanie zręczne, ostrożne, sprytne" (Kopaliński 1983);

- „zręczne, konsekwentne postępowanie jednostki lub grupy zmierzające do osiągnięcia określonego celu" (Słownik wyrazów obcych 1971); 
- „czyjeś zręczne, sprytne, układne działanie w celu osiągnięcia określonych zamierzeń" (Słownik języka polskiego 1988);

- ,przemyślany przez kogoś sposób postępowania mający doprowadzić do osiągnięcia zamierzonego celu; taktyka, strategia" (Wielki słownik... 2009);

- ,oznaczenie konsekwentnego stosowania przez kierownictwo zorganizowanych grup zasad i metod zmierzających do osiągnięcia określonych celów" (Encyklopedia... 2000).

Z przedstawionych ogólnych definicji pojęcia polityki wynika, że jest ono wieloznaczne, można w nich jednak zauważyć pewne wspólne elementy. Polityka wiąże się z czyimś konsekwentnym i przemyślanym działaniem, dążeniem do osiągnięcia wyznaczonego celu. W definicjach tych opisywane jest zatem oddziaływanie (czynność) podmiotu na pewien przedmiot (obiekt) z zamiarem osiągnięcia wyznaczonego celu (zgodnie ze schematem: czynność, podmiot, przedmiot, cel).

Analizując te definicje słowa ,polityka” w kontekście polityki rachunkowości podmiotu gospodarczego, można stwierdzić, że polityka rachunkowości to nie zasady rachunkowości, lecz czynność związana z dokonywaniem wyboru tych zasad (ich dobór). Wybrane zasady rachunkowości są natomiast skutkiem zastosowanej polityki rachunkowości i świadczą o jej realizacji.

W odniesieniu do polityki rachunkowości podmiotu gospodarczego wspomnianą czynnością będzie przemyślany dobór zasad i ich konsekwentne stosowanie, podmiotem - kierownictwo jednostki odpowiadające za prowadzenie rachunkowości, przedmiotem - szczegółowe zasady i specyficzne rozwiązania w zakresie rachunkowości, celem zaś - rzetelny pomiar wielkości ekonomicznych i ich jakościowa prezentacja w sprawozdaniu finansowym.

W kontekście przedstawionych rozważań, zestawiając wszystkie wspólne elementy definicji pojęcia polityki, tj. czynność, podmiot, przedmiot i cel, można dojść do wniosku, że polityka rachunkowości przedsiębiorstwa to przemyślany dobór i konsekwentne stosowanie przez kierownictwo przedsiębiorstwa szczegółowych zasad rachunkowości oraz specyficznych rozwiązań, dopuszczonych w regulacjach rachunkowości (ustawach, krajowych i międzynarodowych standardach), mające na celu rzetelny (prawdziwy) pomiar wielkości ekonomicznych i ich jakościową (wierną) prezentację w sprawozdaniu finansowym. Wydaje się, że w tej definicji, zwracając uwagę na działanie, czynność polegającą na wyborze i stosowaniu określonych rozwiązań, odróżnia się politykę rachunkowości od zasad rachunkowości (przedmiotu takiego działania), a także oddaje istotę tego zagadnienia. 


\section{Polityka rachunkowości w polskim prawie bilansowym i w międzynarodowych standardach rachunkowości}

Polityka rachunkowości została również zdefiniowana i uregulowana w polskim prawie bilansowym (ustawie o rachunkowości i krajowych standardach rachunkowości - KSR), a także w międzynarodowych standardach rachunkowości (MSR). Warto zauważyć, że pojęcie polityki rachunkowości zostało wprowadzone do słownika terminów stosowanych w polskiej ustawie o rachunkowości dopiero nowelizacją ustawy w 2000 r. (obowiązującą od 2002 r.). Wcześniej, w ustawie o rachunkowości uchwalonej w 1994 r. (obowiązującej od 1 stycznia 1995 r.), zamiast terminu „polityka rachunkowości” używano określenia „opis przyjętych zasad rachunkowości”. Określenie to pozbawione było jednak ,pierwiastka celowościowego i zarządczego" i nie wskazywało wprost na intencjonalny charakter doboru stosowanych zasad rachunkowości, z którym wiąże się termin ,polityka” (Walińska i Michalak 2014, s. 123).

Zgodnie z polską ustawą o rachunkowości (art. 3 ust. 1 pkt 11) przez przyjęte zasady (politykę) rachunkowości rozumie się „wybrane i stosowane przez jednostkę rozwiązania dopuszczone ustawą, w tym także określone w MSR, zapewniające wymaganą jakość sprawozdań finansowych”. Trzeba podkreślić, że KSR 7: Zmiany zasad (polityki) rachunkowości, wartości szacunkowych, poprawianie błędów, zdarzenia następujq̨ce po dniu bilansowym - ujęcie i prezentacja (rozdz. II pkt 2.1), w którym określono różne istotne kwestie dotyczące polityki rachunkowości, odwołuje się bezpośrednio do definicji polityki rachunkowości zawartej w ustawie o rachunkowości. A jak wynika z tej definicji, polityka rachunkowości to inaczej przyjęte zasady, czyli wybrane przez jednostkę rozwiązania stosowane $\mathrm{w}$ ściśle określonym celu, jakim jest sporządzenie sprawozdań finansowych wymaganej jakości.

Analizując zapisy MSR, można natomiast zauważyć, że do 30 czerwca 1998 r. polityka rachunkowości była definiowana w MSR 1 jako „zasady, reguły, metody, uzgodnienia umowne i procedury przyjęte przez kierownictwo przedsiębiorstwa przy opracowywaniu i prezentacji sprawozdań finansowych”. Od 1 lipca 1998 r. zmieniony MSR 1 nie zawiera jednak tej definicji. „Politykę rachunkowości” zastąpiły „zasady rachunkowości”. Kolejne zmiany MSR spowodowały, że w 2004 r. przeformułowano MSR 8, którego obecny tytuł to: Polityki rachunkowości, zmiany wartości szacunkowych i korygowanie błędów ${ }^{2}$. Zgodnie z tym standardem polityka rachunkowości są to „konkretne zasady, metody, konwencje, reguły i praktyki

${ }^{2} \mathrm{~W}$ oryginalnej pisowni angielskiej tytuł brzmi: Accounting Policies, Changes in Accounting Estimates and Errors, w wielu polskich przekładach jest on jednak tłumaczony jako: Zasady (polityka) rachunkowości, zmiany wartości szacunkowych i korygowanie błędów (zob. IFRS Standards 2016, IAS 8; Międzynarodowe Standardy... 2011, MSR 8). 
stosowane przez jednostkę przy sporządzaniu i prezentacji sprawozdań finansowych" (IFRS Standards 2016, IAS 8; Stępień 2012, s. 177-178).

Porównując definicje polityki rachunkowości zawarte w polskiej ustawie o rachunkowości i MSR, należy zauważyć, że w MSR wiąże się politykę rachunkowości raczej z pewnymi specyficznymi, ale fundamentalnymi zasadami, podstawami, koncepcjami lub regułami, na których opiera się rachunkowość danego podmiotu gospodarczego. Polityka rachunkowości w języku angielskim tłumaczona jest właśnie jako principles, czyli ogólne zasady, reguły, na których opiera się dana umiejętność, nauka (Longman Dictionary... 1995), lub reguły prawa wyjaśniające mechanizm, proces lub zjawisko (Scribner Dictionary 1986, s. 796). W polskiej ustawie o rachunkowości wiąże się natomiast politykę rachunkowości przedsiębiorstwa raczej ze szczegółowymi rozwiązaniami, zasadami, narzędziami i technikami, które stosuje się w danej jednostce.

Przedstawione różnice w definiowaniu polityki rachunkowości w MSR i polskiej ustawie o rachunkowości przekładają się na zakres znaczeniowy przypisywany temu pojęciu. Z analizy zapisów MSR 8 i ustawy o rachunkowości wynika, że polityka rachunkowości zgodnie z definicją zawartą w MSR 8 dotyczy wyłącznie problemów merytorycznych z zakresu rachunkowości, tj.: uznawania, ujmowania, wyceny, prezentacji i ujawniania informacji o transakcjach, innych zdarzeniach lub warunkach. Zgodnie z ustawą o rachunkowości (art. 10 ust. 1) pojęcie to odnosi się natomiast zarówno do problemów merytorycznych z zakresu rachunkowości, jak i problemów technicznych oraz organizacyjnych, sprowadzających się do sposobu prowadzenia ksiąg rachunkowych i ich ochrony (Krzywda 2013b, s. 16).

Zgodnie z art. 10 ust. 1 ustawy o rachunkowości przyjęte przez jednostkę zasady (polityka) rachunkowości obejmują w szczególności rozwiązania dotyczące:

- określenia roku obrotowego i wchodzących w jego skład okresów sprawozdawczych,

- metod wyceny aktywów i pasywów oraz ustalania wyniku finansowego,

- sposobu prowadzenia ksiąg rachunkowych,

- systemu służącego ochronie danych i ich zbiorów.

Zgodnie z art. 5 ust. 1 ustawy o rachunkowości przyjęte zasady (politykę) rachunkowości należy stosować w sposób ciągły, dokonując w kolejnych latach obrotowych jednakowego grupowania operacji gospodarczych, wyceny aktywów i pasywów, w tym także odpisów amortyzacyjnych lub umorzeniowych, ustalając wynik finansowy i sporządzając sprawozdania finansowe tak, aby wynikające z nich informacje za kolejne lata były porównywalne.

Jak wynika z przytoczonych przepisów prawnych, zasady (polityka) rachunkowości obejmują zatem wybrane przez jednostkę rozwiązania, dotyczące m.in. (pkt $3.1 \mathrm{KSR} 7$, art. 10 ust. 1 ustawy o rachunkowości): 
- zasad klasyfikacji i grupowania zdarzeń, metod wyceny aktywów i pasywów oraz ustalania wyniku finansowego i prezentacji (wykazywania lub ujawniania) w sprawozdaniu finansowym, a więc problemów merytorycznych z zakresu rachunkowości,

- techniczno-organizacyjnego sposobu prowadzenia ksiąg rachunkowych i ich ochrony, czyli problemów natury technicznej i organizacyjnej.

Trzeba jednocześnie zaznaczyć, że wspomniana powyżej problematyka merytoryczna rachunkowości stanowi równocześnie przedmiot uregulowań KSR 7, w przeciwieństwie do problematyki techniczno-organizacyjnej, której zagadnienia nie są przedmiotem regulacji KSR 7 (Krzywda 2013b, s. 16).

Podobne spostrzeżenia nasuwają się w kontekście poglądów mistrzyni polskiej rachunkowości A. Jarugowej na temat polityki rachunkowości, które przytaczają E. Walińska i M. Michalak (2014, s. 125): „utożsamianie polityki rachunkowości z technicznym wymiarem systemu rachunkowości, związanym z prowadzeniem ksiąg rachunkowych, jest wyrazem silnego przywiązania do rozwiązań i doświadczeń ukształtowanych w warunkach systemu gospodarki centralnie planowanej i sprowadzenia rachunkowości finansowej głównie do realizacji funkcji ewidencyjnej, według z góry założonych zasad. Rozumienie polityki rachunkowości zgodne z podejściem Profesor Alicji Jarugowej prowadziło wyraźnie do rozdzielania odpowiedzialności za sprawozdawczość finansową od odpowiedzialności za realizację obowiązków ewidencyjnych w rachunkowości finansowej”. Relacje między polityką rachunkowości a podsystemem ewidencyjnym rachunkowości finansowej w tym ujęciu przedstawiono na rys. 1.

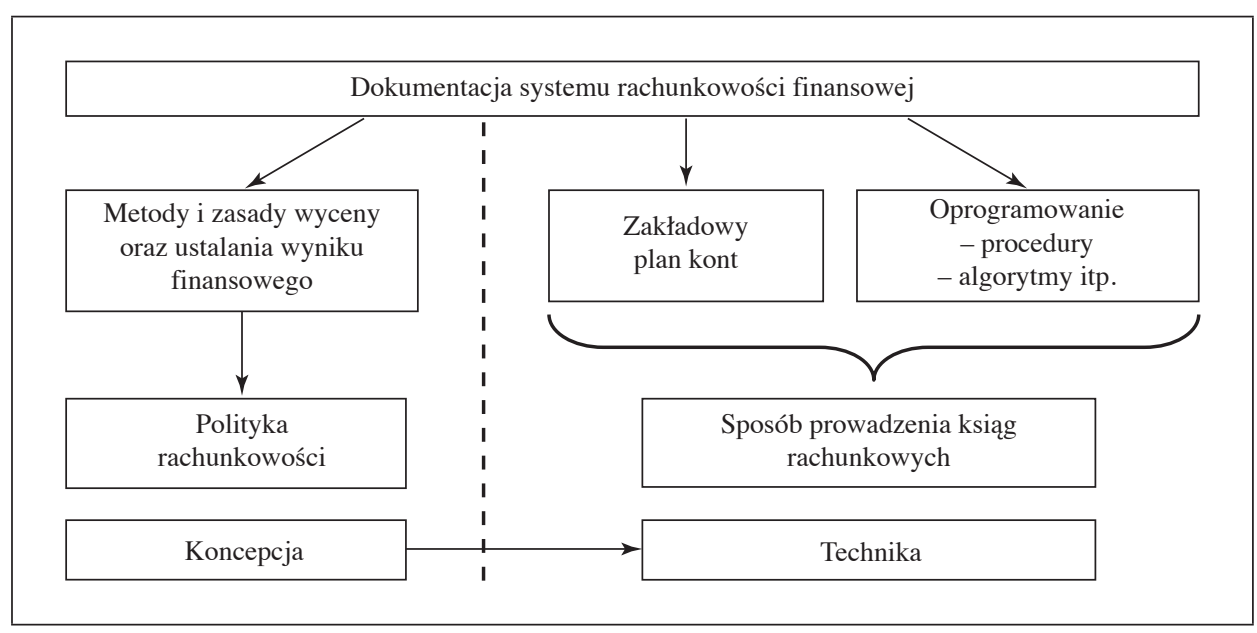

Rys. 1. Relacje między polityką rachunkowości a podsystemem ewidencyjnym rachunkowości finansowej Źródło: (Walińska i Michalak 2014, s. 126). 
Wskazane jest więc wyraźne odróżnienie kwestii techniczno-organizacyjnych rachunkowości od faktycznego zakresu przedmiotowego polityki rachunkowości. Warto podkreślić, że definicja polityki rachunkowości zawarta w MSR jest dużo bardziej zbliżona pod względem przedstawionego zakresu przedmiotowego do definicji polityki rachunkowości prezentowanych w literaturze przedmiotu niż ta sformułowana w polskiej ustawie o rachunkowości.

Kolejną różnicą w definiowaniu polityki rachunkowości w MSR i polskiej ustawie o rachunkowości jest to, że w ustawie o rachunkowości wprost określono cel polityki rachunkowości - zapewnienie wymaganej jakości sprawozdań finansowych. W ustawie o rachunkowości wskazuje się także na szerszy zakres regulacji w zakresie rachunkowości: zarówno ustawę, jak i MSR, w MSR natomiast nie określono bezpośrednio celu polityki rachunkowości. Zwrócono uwagę jedynie na obszary wykorzystania polityki rachunkowości - sporządzanie i prezentację sprawozdań finansowych (Walińska 2016, s. 187).

Pomimo występowania istotnych różnic w definicjach polityki rachunkowości zawartych w MSR i polskiej ustawie o rachunkowości istnieją w tym zakresie także pewne podobieństwa. Zarówno w ustawie o rachunkowości, jak i w MSR utożsamia się politykę rachunkowości raczej z jej przedmiotem, czyli zasadami, regułami bądź rozwiązaniami, a nie z czynnością, działaniem polegającym na doborze tych zasad, reguł czy rozwiązań. W ustawie o rachunkowości słowo „polityka” zamieszczono w nawiasie obok słowa „zasady”, sugerując, że są to synonimy.

Utożsamianie polityki rachunkowości (czynności, działania) z jej przedmiotem (zasadami, rozwiązaniami) nie jest właściwe, zwłaszcza w kontekście uwag dotyczących istoty polityki rachunkowości. Warto zatem jeszcze raz podkreślić, że polityka rachunkowości to nie zasady rachunkowości, lecz czynność związana z wyborem tych zasad (ich dobór). Wybrane zasady rachunkowości są bowiem skutkiem zastosowanej polityki rachunkowości i świadczą o jej realizacji.

\section{Polityka rachunkowości w kontekście wielkości szacunkowych}

Analizując zakres merytoryczny określenia „polityka rachunkowości” $\mathrm{w}$ aspekcie prawnych regulacji w zakresie rachunkowości, trzeba wspomnieć o pokrewnej kategorii pojęciowej, jaką są wielkości (wartości) szacunkowe. Zarówno w polskiej ustawie o rachunkowości, jak i w MSR rozróżnia się te pojęcia i przewiduje różne skutki w wypadku dokonywania zmian w tych kategoriach rachunkowych. $Z$ dużym uogólnieniem można stwierdzić, że konieczność zapewnienia porównywalności informacji prezentowanych w sprawozdaniach finansowych przedsiębiorstw przesądza o retrospektywnym zastosowaniu zmian 
polityki rachunkowości, w odróżnieniu od prospektywnego zastosowania zmian wielkości szacunkowych. Wymienione sposoby zastosowania zmian różnią się znacznie stopniem złożoności i związaną z tym pracochłonnością, co jest szczególnie istotne dla praktyki rachunkowości (Krzywda 2013b, s. 16).

W przeciwieństwie do terminu „polityka rachunkowości” wyrażenie „wartości szacunkowe" nie jest definiowane wprost w ustawie o rachunkowości ani w MSR. Definicja wartości szacunkowych jest jednak zawarta w KSR 7, a w MSR 8 podano z kolei definicję zmian wartości szacunkowej. Zgodnie z KSR 7 (pkt 2.12) wartości szacunkowe są to „przybliżone kwoty pieniężne przyjęte przez jednostkę do wyceny określonych składników aktywów lub pasywów, bądź przychodów i kosztów wobec niemożności dokładnej ich wyceny". Stosownie do MSR 8 (par. 5) zmiana wartości szacunkowej jest to natomiast: „korekta wartości bilansowej składnika aktywów albo zobowiązania, bądź okresowego zużycia składnika aktywów, będąca wynikiem oceny bieżącego stanu oraz oczekiwanych przyszłych pożytków i obowiązków związanych z tymi aktywami i zobowiązaniami. Zmiany wartości szacunkowych mogą być rezultatem uzyskania nowych informacji lub nowych działań, i w związku z tym, nie stanowią korekt błędów".

Ustalenia wartości szacunkowych dokonuje się w drodze osądu, na podstawie wiarygodnych informacji, z zastosowaniem właściwych w danych warunkach metod szacunku. Przedmiotem szacunku mogą np. być (pkt 4.1 KSR 7; Krzywda 2013a, s. 135; Stępień 2013, s. 72):

- okresy użytkowania podlegających amortyzacji środków trwałych, wartości niematerialnych i prawnych,

- należności, których ściągalność jest wątpliwa,

- zapasy wyceniane w cenach sprzedaży netto wobec utraty przez nie przydatności gospodarczej dla jednostki,

- aktywa i rezerwy z tytułu odroczonego podatku dochodowego,

- rezerwy na zobowiązania i traktowane na równi z nimi bierne rozliczenia międzyokresowe kosztów,

- odpisy z tytułu utraty wartości aktywów.

Wartości szacunkowe mają fundamentalne znaczenie w rachunkowości. Ich zastosowanie podczas wyceny w rachunkowości ma na celu ujmowanie na bieżąco (w bieżącym sprawozdaniu finansowym) ryzyka gospodarczego, wiążącego się z niekorzystnymi sytuacjami, stratami, jakie mogą nastąpić w przyszłości, a które w danej chwili są możliwe do przewidzenia. W konsekwencji użycie wartości szacunkowych przyczynia się do zabezpieczenia zasobów jednostki gospodarczej. Rachunkowość, wykorzystując do wyceny zasobów wartości szacunkowe, daje jednostkom sposobność do podjęcia działań wyprzedzających rzeczywiste zdarzenia (Micherda 2006, s. 113; Stępień 2013, s. 72). 
Wprawdzie w regulacjach prawnych z zakresu rachunkowości odróżnia się pojęcie polityki rachunkowości od wartości szacunkowych, w szczególności w kontekście zmian tych kategorii rachunkowych, określenia te są jednak z sobą istotnie związane. Świadczy o tym choćby definicja zawarta w MSR 8. Analizując tę definicję, można dojść do wniosku, że polityka rachunkowości, rozumiana jako „konkretne zasady, metody, konwencje, reguły i praktyki stosowane przez jednostkę przy sporządzaniu i prezentacji sprawozdań finansowych", odnosi się także do wielkości szacunkowych. Ustalanie wartości szacunkowych można uznać za element polityki rachunkowości przedsiębiorstwa, określając bowiem wielkość szacunkową jakiegoś zasobu, jednostka kieruje się subiektywną oceną i dokonuje konkretnych (subiektywnych) wyborów w zakresie różnych możliwości. Przykładem może być wyznaczanie stopy amortyzacji środka trwałego, która jest zależna od długości okresu jego użytkowania. Jednostka sama dokonuje subiektywnych prognoz eksploatacji takiego środka trwałego i może przyjąć różne rozwiązania (np. 5 albo 8 lat). Poza tym może ten okres skracać lub wydłużać w zależności od subiektywnych ocen nowych okoliczności.

W kontekście definicji polityki rachunkowości zawartej w MSR 8 ustalanie wielkości szacunkowych można zatem traktować jako element polityki rachunkowości przedsiębiorstwa. Warto jednak zauważyć, że definicja polityki rachunkowości sformułowana w MSR 8 nie jest spójna z jego dalszą częścią, w której wyraźnie odróżnia się zmiany w polityce rachunkowości od zmian wielkości (wartości) szacunkowych. Można więc mówić o polityce rachunkowości w szerszym i węższym znaczeniu (Kabalski 2009, s. 21).

Polityka rachunkowości w szerszym znaczeniu (sensu largo) oznacza wszelkie sposoby postępowania przyjęte przez podmiot przy sporządzaniu sprawozdań finansowych i mające zapewnić, że informacje zawarte w sprawozdaniach finansowych będą przydatne i wiarygodne. W takim ujęciu w ramach polityki rachunkowości mieszczą się także stosowane przez jednostkę metody wyznaczania wartości szacunkowych, np. naliczania odpisów amortyzacyjnych, pomiaru stopnia zaawansowania usługi wielookresowej, techniki szacowania wartości godziwej różnych składników aktywów (inne dla nieruchomości, inne dla aktywów finansowych) itp. Polityka rachunkowości w węższym znaczeniu (sensu stricto) odnosi się natomiast do sytuacji, w których zgodnie z określonymi standardami pozostawia się jednostce prawo wyboru (np. sposobu wyceny środków trwałych - zastosowania modelu kosztu historycznego lub modelu przeszacowania). W tym ujęciu polityka rachunkowości nie obejmuje jednak takich elementów jak wspomniany sposób amortyzacji czy metoda pomiaru stopnia zaawansowania usługi (Kabalski 2009, s. 21).

W kontekście powyższych spostrzeżeń warto podkreślić, że gdy w MSR jest mowa o zmianach w polityce rachunkowości (a w szczególności o tym, kiedy jednostka może ich dokonać i jak powinna je ująć), chodzi wyłącznie o politykę 
rachunkowości w węższym znaczeniu. Zakres polityki rachunkowości w kontekście regulacji prawnych i środowiskowych zaprezentowano na rys. 2.

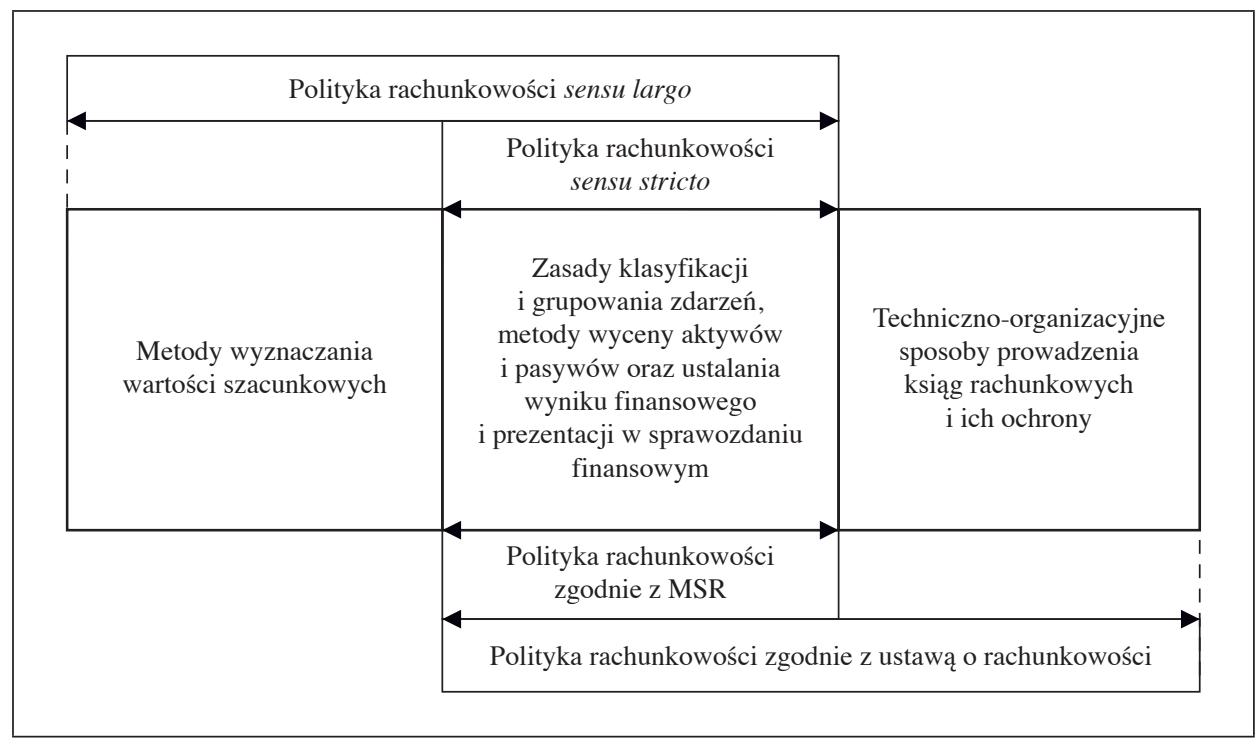

Rys. 2. Zakres polityki rachunkowości w kontekście regulacji prawnych i środowiskowych

Źródło: opracowanie własne.

Jak wynika z rys. 2, zakres polityki rachunkowości przedsiębiorstwa jest różnie określany, i to zarówno w literaturze przedmiotu, jak i regulacjach prawnych. Polityka rachunkowości sensu stricto koncentruje się na wyborze szczegółowych i merytorycznych zasad, koncepcji i rozwiązań, których prawo swobodnego wyboru wyznaczają regulacje rachunkowości, z pominięciem jednak metodyki wyznaczania wartości szacunkowych. Polityka rachunkowości w tym wąskim rozumieniu odnosi się zatem w szczególności do doboru zasad klasyfikacji i grupowania zdarzeń, metod wyceny aktywów i pasywów oraz ustalania wyniku finansowego, a także zasad prezentacji wielkości ekonomicznych w sprawozdaniu finansowym przedsiębiorstwa. Polityka rachunkowości sensu largo obejmuje z kolei również wybór metod wyznaczania wartości szacunkowych.

Zakres polityki rachunkowości określony w MSR jest w istocie zbieżny z tym wyznaczonym w węższym ujęciu tego pojęcia. Zakres polityki rachunkowości określony w polskiej ustawie o rachunkowości jest natomiast dość specyficzny, ponieważ oprócz zakresu wyznaczonego w węższym ujęciu obejmuje także techniczno-organizacyjne sposoby prowadzenia i archiwizowania ksiąg rachunkowych. 


\section{Podsumowanie}

Polityka rachunkowości wywiera istotny wpływ na wartość informacyjną sprawozdań finansowych przedsiębiorstwa. Mimo że odgrywa tak istotną rolę, jest pojęciem wieloznacznym i różnie rozumianym. Często bywa utożsamiana z zasadami rachunkowości.

Z przedstawionych rozważań można wyciągnąć następujące wnioski:

- polityka rachunkowości może być rozpatrywana w kilku wymiarach: globalnym, makroekonomicznym oraz mikroekonomicznym,

- polityka rachunkowości w ujęciu mikroekonomicznym jest utożsamiana z polityką rachunkowości przedsiębiorstwa,

- polityka rachunkowości to nie zasady rachunkowości, lecz czynność związana z dokonywaniem wyboru tych zasad (ich dobór), wybrane zasady rachunkowości są natomiast efektem zastosowanej polityki rachunkowości i świadczą o jej realizacji,

- polityka rachunkowości w regulacjach prawnych z zakresu rachunkowości (ustawie o rachunkowości, MSR) utożsamiana jest z zasadami lub rozwiązaniami szczegółowymi rachunkowości,

- istnieje rozbieżność w określaniu zakresu polityki rachunkowości w polskiej ustawie o rachunkowości i MSR (definicja polityki rachunkowości zawarta w ustawie oprócz kwestii merytorycznych ujętych w MSR obejmuje również problemy natury techniczno-organizacyjnej rachunkowości),

- zarówno w ustawie o rachunkowości, jak i w MSR rozróżnia się pojęcia polityki rachunkowości i wielkości szacunkowych, podczas gdy w teorii rachunkowości ustalanie wartości szacunkowych może wchodzić w zakres polityki rachunkowości przedsiębiorstwa,

- można wyróżnić politykę rachunkowości sensu stricto i sensu largo.

Polityka rachunkowości jest więc pojęciem złożonym. Różnie też określany jest jej zakres, i to zarówno w teorii, jak i w regulacjach prawnych dotyczących rachunkowości.

Wydaje się, że warto byłoby doprecyzować definicje polityki rachunkowości zawarte w regulacjach prawnych z zakresu rachunkowości, uwzględniając uwagi przedstawione $\mathrm{w}$ rozważaniach teoretycznych. Wskazane byłoby ponadto ujednolicenie zakresu polityki rachunkowości określonego w regulacjach prawnych poprzez dostosowanie polskich rozwiązań do rozwiązań międzynarodowych. 


\section{Literatura}

Brzezin W. (2000), Mikro- i makropolityka rachunkowości. Normy prawne i zawodowe rachunkowości, „Prace Naukowe Akademii Ekonomicznej we Wrocławiu”, nr 876.

Encyklopedia popularna PWN (2000), PWN, Warszawa.

Glautier M.W.E., Underdown B. (1997), Accounting Theory and Practice, Pitman Publishing, London.

Hendriksen E.A., van Breda M.F. (2002), Teoria rachunkowości, PWN, Warszawa.

IFRS Standards (2016), IFRS Foundation, London.

Jarugowa A., Walińska E. (1997), Roczne sprawozdania finansowe. Ujęcie księgowe a podatkowe, ODDK, Gdańsk.

Kabalski P. (2009), Polityka rachunkowości w spółce stosujq̨cej MSSF, SKwP, Warszawa.

Karmańska A. (2010), Wielowymiarowość polityki rachunkowości i etyki z niq zwiqzanej (artykuł dyskusyjny), ,Zeszyty Teoretyczne Rachunkowości”, t. 56(112).

Kieso D.E., Weygandt J.J. (1992), Intermediate Accounting, John Wiley \& Sons, New York.

Kinserdal A. (1995), Financial Accounting: An International Perspective, Pitman Publishing, London.

Kopaliński W. (1983), Słownik wyrazów obcych i zwrotów obcojęzycznych, Wiedza Powszechna, Warszawa.

Krajowy Standard Rachunkowości nr 7: Zmiany zasad (polityki) rachunkowości, wartości szacunkowych, poprawianie błędów, zdarzenia następujące po dniu bilansowymujęcie $i$ prezentacja, http://www.mf.gov.pl/c/document_library/get_file?uuid= dccd820b-46f5-44a6-a574-d64a0d32d47a\&groupId=764034 (data dostępu: 4.01.2017).

Krzywda D. (2013a), Polityka rachunkowości a wartości szacunkowe $w$ aspekcie zasady ciqgłości (w:) Współczesne uwarunkowania kwantyfikacji w rachunkowości, red. B. Micherda, Difin, Warszawa.

Krzywda D. (2013b), Zmiany zasad (polityki) rachunkowości, wartości szacunkowych, poprawianie błędów, zdarzenia następujqce po dniu bilansowym - ujęcie i prezentacja, SKwP, Warszawa.

Longman Dictionary of Contemporary English (1995), Longman, Harlow.

Micherda B. (2006), Problemy wiarygodności sprawozdania finansowego, Difin, Warszawa.

Międzynarodowe Standardy Sprawozdawczości Finansowej (2011), SKwP-IFRS, Warszawa.

Remlein M. (2007), W poszukiwaniu ładu terminologicznego. Polityka rachunkowości, polityka bilansowa, zasady rachunkowości (w:) Rachunkowość w teorii i praktyce, t. 1: Rachunkowość finansowa, red. W. Gabrusewicz, Wydawnictwo Akademii Ekonomicznej w Poznaniu, Poznań.

Saudagaran S.M. (2009), International Accounting: A Users Perspective, CCH a Wolters Kluwer business, Chicago, Illinois.

Scribner Dictionary (1986), red. W.D. Halsey, Glencoe, Mission Hills, California.

Słownik jezzyka polskiego (1988), red. M. Szymczak, PWN, Warszawa.

Słownik wyrazów obcych PWN (1971), red. J. Tokarski, PWN, Warszawa.

Stępień K. (2012), Polityka rachunkowości jako przedmiot badania biegłego rewidenta (w:) Zawartość informacyjna polityki rachunkowości. Wybrane problemy, red. H. Żukowska, B. Sawicka, Wydawnictwo KUL, Lublin. 
Stępień K. (2013), Stosowanie wielkości szacunkowych a wiarygodność wyceny w rachunkowości (w:) Współczesne uwarunkowania kwantyfikacji w rachunkowości, red. B. Micherda, Difin, Warszawa.

Ustawa z dnia 29 września 1994 r. o rachunkowości, Dz.U. z 2009 r. nr 152, poz. 1223 ze zm. Walińska E. (2010), Polityka rachunkowości, błędy lat poprzednich i zmiany szacunków (w:) Rachunkowość finansowa. Ujęcie sprawozdawcze i ewidencyjne, red. E. Walińska, Oficyna a Wolters Kluwer business, Warszawa.

Walińska E. (2016), Sprawozdanie z polityki rachunkowości jako odrębny składnik sprawozdania finansowego, ,Zeszyty Teoretyczne Rachunkowości”, nr 87(143).

Walińska E., Michalak M. (2014), Polityka rachunkowości w kontekście poglądów naukowych Profesor Alicji Jarugowej, ,Zeszyty Teoretyczne Rachunkowości”, nr 80(136).

Wielki słownik języka polskiego (2009), red. J.B. Dunaj, Buchmann, Warszawa.

\section{The Concept and Scope of Accounting Policy in Polish and International Accounting Regulations}

(Abstract)

Accounting policy can be interpreted and defined in numerous ways. It is often associated with the principles of accounting. The scope of accounting policy is also determined in a variety of ways.

The study examines accounting policy in the context of accounting principles and defines the concept of accounting policy. It compares the scope of accounting policy defined in Polish and international accounting regulations and indicates differences in this area. In so doing, it analyses the subject literature and legal acts, comparing them and drawing deductions.

Currently, Polish legal regulations do not match international regulations in terms of how they define accounting policy and its scope. While Poland is gradually adjusting its regulations to EU regulations, the scope of accounting policy has still not been standardized.

The analysis shows that accounting policy is not determined by accounting principles, but by the choosing if these principles. The selected accounting policies are the result of accounting policy and evidence of its implementation. On the other hand, in accounting regulations (Polish Accounting Act, IAS), accounting policy is synonymous with the principles or as detailed accounting solutions, which is incorrect. In addition, there is considerable discrepancy in the scope of accounting policy in the Polish Accounting Act and IAS.

Keywords: accounting policy, accounting rules, estimated values, accounting regulations. 